\title{
Physical and Mechanical Assessments of Fire Retardant-Treated Shorea macrophylla and Acacia mangium Particleboards
}

\author{
Izran Kamal (Corresponding author), Khairul Masseat, Koh Mok Poh, Tan Yu Eng \\ Saimin Basir, Nordin Puteh, Rosly Mat Joha \& Naziffuad Noran \\ Forest Research Institute Malaysia (FRIM), 52109, Kepong, Malaysia \\ Tel: 60-3-6279-7285_E-mail: izran_kamal@yahoo.com
}

The research is financed by FRIM-ITTO 50300304008

\begin{abstract}
Physical and mechanical properties of fire retardant-treated engkabang (Shorea macrophylla) and Acacia mangium particleboards were assessed. Tests selected for the assessments were water absorption, thickness swelling, modulus of rupture (MOR), modulus of elasticity (MOE) and internal bond (IB). The engkabang and Acacia mangium particles were mixed with $10 \% \mathrm{w} / \mathrm{w}$ of two different fire retardants namely zinc borate $\left(4 \mathrm{Zn} 0.6 \mathrm{~B}_{2} \mathrm{O}_{3} .7 \mathrm{H}_{2} \mathrm{O}\right)$-simplified as $\mathrm{ZBr}$ and monoammonium phosphate $\left.\left(\mathrm{NH}_{4}\right) \mathrm{H}_{2} \mathrm{PO}_{4}\right)$ during the mixing stage of the particleboard manufacturing processes. The properties of the particleboards were tested using British European 1993 standard. An analysis of variance was carried out to study the effects of fire retardant types on the boards of both species. The study showed that MAP-treated particleboards were superior to ZBr-treated particleboards for both mechanical and physical performances except for modulus of elasticity (MOE). Overall, the fire retardants reduced the physical and mechanical properties of the engkabang and Acacia mangium particleboards. However, all treated and untreated particleboards complied with the standard requirement values and these findings are expected to increase the promotion of both species to be used in producing fire-retardant particleboards.
\end{abstract}

Keywords: Fire retardants, Internal bond, Modulus of rupture, Modulus of elasticity, Zinc borate and monoammonium phosphate

\section{Introduction}

Engkabang jantung (Shorea macrophylla) and Acacia mangium_are two of the most popular wood species that frequently used as inputs for interior decoration such as cabinets, furnitures, and turnery. The plants are also used for particleboard, plywood, veneer, pulp, fence, firewood and charcoal (Sanchez, 2006, Anon,2009). Mohamad Azani et al., (2001) studied that engkabang jantung can grow very fast and form wide spreading crowns, even though it is planted under shades of the higher trees. Engkabang is a protected species and can be found scattering throughout Sarawak, usually on clay alluvial soil of riparian forest and lower slopes of clay hill sides below 600m above sea level (Anon, 2009 and Anon 2009a). The information about this species is still limited compared to Acacia mangium. Engkabang is popular due to its nut known as False Illipe Nut, which has moisturising properties that are similar to cocoa butter for skincare and haircare products (Fleckenstein, 2009). Like engkabang jantung, Acacia mangium is a fast growing species too. Acacia mangium can be found on many different types of sites such as primary and secondary forests, forest margin, savannah, grassland, savanna woodland, mangrove forest and abandoned shifting cultivation sites (Sanchez, 2006). This species can achieve $15 \mathrm{~m}$ height within 3 years, even when it is planted on mining degraded sites (Velez Torres and Valle Del, 2007), giving it a short rotation. It is also relatively free from disease. Tropical forest is disappearing at the rate of 15-20 million ha/year. The rate might increase if the usage upon the forest resources is not controlled. Due to that, the wood-based product manufacturers would like to find new raw materials that can reduce the pressure bears by the forest elimination rate (Xavier, 2009). Acacia mangium and engkabang are two crops with high potential for that purpose. Thereby, this research is to promote these two species as raw materials for fire retardant-treated particleboard. The specific aim of this study is evaluate the physical and mechanical properties of the fire retardant-treated particleboards made of engkabang and Acacia mangium.

\section{Materials and Method}

\subsection{Materials}

Engkabang (Shorea macrophylla) and Acacia mangium were used in this research. The logs of engkabang were 
brought from Sarawak Forest Department and the Acacia mangium logs were supplied by Asia Prima, Mentakab and Aramijaya Ulu Selidi, Johore. The logs of both species were grinded separately and then were flaked using Knife Ring Flaker at Wood Composite Workshop, Forest Research Institute (FRIM). The flakes were screened and only particles with size $1-2 \mathrm{~mm}$ were taken and were spread on the oven trays for drying. The particles were dried at $105 \pm 2^{\circ} \mathrm{C}$ to reduce the moisture content to $5 \%$ before they were mixed with adhesive. Adhesive used in this study was urea formaldehyde (UF) supplied by Malaysian Adhesive Company Sdn. Bhd., Shah Alam. Two fire retardants were selected to be scattered onto the particles-adhesive mixtures i.e monoammonium phosphate (MAP) and zinc borate $\left(4 \mathrm{Zn} 0.6 \mathrm{~B}_{2} \mathrm{O}_{3} .7 \mathrm{H}_{2} \mathrm{O}\right)$ during the mixing stage.

\subsection{Manufacture of Acacia mangium and engkabang boards}

The targeted board density was $700 \mathrm{~kg} / \mathrm{m}^{3}$. About $897.29 \mathrm{~g}$ dried particles, $182 \mathrm{~g}$ UF resin, $27.31 \mathrm{~g}$ hardener and $14.2 \mathrm{~g}$ wax were needed to fabricate a particleboard with that targeted density as exhibited in Table 1 . The dried particles with the $5 \% \mathrm{MC}$ were placed into the particleboard mixer. Adhesive-wax-hardener combination was sprayed to the particles in the mixer by using airless spray gun which was attached on top of the mixer. Once the particles were mixed evenly with the adhesive, the particleboard mixer was turned off and $10 \% \mathrm{w} / \mathrm{w}$ fire retardant was placed on the furnish (Figure 1). The amount of fire retardant for the targeted density is determined by following the previous study done by (Izran et al.,2009). That amount of fire retardant was found effective to increase the fire resistance of the particleboards. The particleboard mixer with the mixture of particles-fire retardant-adhesive in it was re-operated for the next $5 \mathrm{~min}$ to make sure that the fire retardant was evenly scattered. The moisture content of the furnish was $12 \% \mathrm{MC}$. The $\mathrm{MC}$ was determined using Moisture Content Calculator. The furnish was then placed in a former, cold-pressed and subsequently pressed in a hot press at $165^{\circ} \mathrm{C}$ (Figure 2). The temperature of the hot press was increased to that temperature in intention to dismiss excessive water of the furnish, which was being absorbed from the surrounding during the mixing and cold pressing stages. The pressing time for each treatment varied from 6 to 9 minutes. Variations in pressing time for different fire retardant types were occupied based on the effect of fire retardant to the gelation time of the adhesive. Effects of phosphorous and boric-based fire retardants to the gelation time of UF adhesive was reported by (Izran et al.,2010 and Izran et al.,2009a). The MAP-mixed furnish was pressed for 6 min, slightly shorter than the control which was pressed for $7 \mathrm{~min}$. Zinc borate-mixed furnish was pressed for 9 min due to the alkalinity of the fire retardant that was expected to delay the curing of the UF resin. The particleboards were exposed to the surrounding before they were brought to the conditioning room and conditioned at $20 \pm 2^{\circ} \mathrm{C}$ and $65 \pm 2 \%$ relative humidity until equilibrium, i.e $12 \%$ for 1 week. Total of three boards for each treatment were trimmed according to the standard requirement size and were distributed for the strength tests.

\subsection{Physical and mechanical evaluations}

The tests were conducted in accordance with British Standard EN. The physical and mechanical testing conducted were static bending (BS EN 310:1993), thickness swelling and water absorption (BS EN 317:1993), internal bond (BS EN 319:1993) and density (BS EN 323:1993). Ten blocks were distributed for each test. The blocks were randomly cut from each of the untreated and treated boards and conditioned in the conditioning room until they reached constant weights. The particleboard were cut to two sizes of blocks: 1) $50 \times 50 \times 12 \mathrm{~mm}$ for internal bond and thickness swelling, 2) $240 \times 50 \times 12 \mathrm{~mm}$ for modulus of rupture (MOR) and modulus of elasticity (MOE). The mean values of the samples obtained from the tests were analyzed using ANOVA, to study the relationship between the fire retardant types and the strength of the engkabang and Acacia mangium particleboards.

\section{Results and Discussions}

The data are summarised and presented in Table 2. For modulus of rupture (MOR) and modulus of elasticity (MOE) values, the negative signs indicate a reduction in the value of properties, while for thickness swelling and water absorption, the negative sign reflects an improvement in dimensional stability. The treated samples were compared with the untreated samples in order to investigate the effects of the fire retardants to the physical and mechanical performances.

\subsection{Physical properties}

Thickness swelling is to measure the dimensional stability of the particleboards. Lower thickness swelling value indicates a more stable board. There were two different thickness swelling tests conducted i.e $2 \mathrm{~h}$ immersion in cold water and $24 \mathrm{~h}$ immersion in cold water. The results show the fire-retardant treatments reduced the dimensional stability and increase the water absorption of the particleboards for both species. The longer the immersion the greater the thickness swelling and the amount of water absorbed. The differences between the treated engkabang and Acacia mangium to the untreated, when they were immersed for $2 \mathrm{~h}$ were $-0.77,2.63,1.34$ 
and $3.63 \%$ respectively. As for water absorption test, the differences were $-0.38,2.7,1.1$ and $4.68 \%$ respectively. Similar result patterns were recorded for samples immersed for $24 \mathrm{~h}$ but greater than $2 \mathrm{~h}$ : $-4.68,4.68,11.28$, $17.25 \%$ for thickness swelling and $-9.7,18.82,15.24$ and $27.99 \%$ for water absorption. The differences indicate that the MAP-treated engkabang was more stable than the untreated. The ZBr-treated engkabang and Acacia mangium were less dimensionally stable than their treated counterparts with MAP. Naturally, fire retardants are hygroscopic and they are able to increase the water absorption of the treated particleboards. This claim has been investigated in depth (Izran et al., 2009 and Izran et al.,2009a), where it was found that kenaf core particleboard treated with phosphorous-based fire retardants (MAP, BP®, and diammonium phosphate) presented increase of thickness swelling from 10.11 to $35.91 \%$ and water absorption from -3.79 up to $35.91 \%$ respectively. It was also recorded that the TS and WA can become worse if the amount or concentration of fire retardants is increased (Abdul Rashid et al.,1990, Muehl et al., 1999 and Winandy et al., 2008)

\subsection{Mechanical Properties}

The treated particleboards tended to have lower mechanical properties compared with the untreated, but generally, the treated particleboards complied with the standard requirements. Results in Table 2 show that $\mathrm{ZBr}$ caused greater reduction of most mechanical strength properties for both species than MAP. The MOR values for particleboards treated with $\mathrm{ZBr}$ for Acacia mangium and engkabang were 13.23 and 14.08 respectively, which were significantly lower compared to untreated particleboards i.e 21.17 and $20.38 \mathrm{~N} / \mathrm{mm}^{2}$ and those treated with MAP i.e 14.42 and $17.42 \mathrm{~N} / \mathrm{mm}^{2}$. Similar results can be seen for MOE except for the treated Acacia mangium particleboards. For engkabang, once again, ZBr-treated possessed the lowest MOE value i.e $3155 \mathrm{~N} / \mathrm{mm}^{2}$ compared with the untreated and MAP-treated, which the MOE values were 3924 and $3337 \mathrm{~N} / \mathrm{mm}^{2}$. For Acacia mangium, the MAP-treated particleboards were significantly lower than that of ZBr. The ZBr-treated MOE value was 2940 and the MAP-treated was $2818 \mathrm{~N} / \mathrm{mm}^{2}$. However, the values were still lower than the original stiffness of the untreated i.e $3483 \mathrm{~N} / \mathrm{mm}^{2}$. There were no significant differences of internal bond (IB) between the untreated and treated particleboards for engkabang and Acacia mangium. However, the result pattern was similar with that of MOR, where the ZBr-treated, still presented lower values compared with the untreated and MAP-treated. The different UF adhesive curing rate as it was mixed with fire retardants, which brought to the longer and shorter hot pressing time was expected to be a factor that influencing the MOR, MOE and IB of the treated particle boards (Izran et al., 2008, 2009 2009a and 2009b). The ZBr-treated furnish was exposed to the heat longer as it required longer pressing time than other furnishes and these could cause slight decreases in internal bond. The effect of the hot pressing time on the strength of the particleboard has been investigated by Zhiyong et al. (2006), who fabricated medium density fibreboard with five different pressing schedules. They found that as the press platen was closing from 90 to $160 \%$ the MOE value decreased from 110 to $70 \%$. It was also suspected that strength loss occurred during chemical treatment and subsequent redrying of the panel (White and Sweet, 1992). Thus, modifications on the hot pressing time and temperature are required to fully cure the resin and at the same time preserving the strength of the particles.

\section{Conclusions}

The findings from this study revealed that flame retardant treatments significantly affect the physical and mechanical properties of the engkabang and Acacia mangium particleboards. The fire retardants were found to affect the curing of the resin and modification on the hot pressing time was occupied to be sure that the resin is fully cured and compact particleboards could be produced. The reductions of the mechanical properties maybe the result of the hot pressing temperature, time and subsequent re-drying of the particleboards. Between species, engkabang appears to possess better physical and mechanical performances compared to Acacia mangium, for both fire retardant types. However for both species, treated and untreated, generally complied with the standard requirements. As a whole, the treatment system used in this study may be suitable for the manufacturing of fire retardant-treated particleboard from engkabang and Acacia mangium. It appears possible increase in resistivity against thermal degradation may further expand the usage of the panels and will be discussed in future papers.

\section{Acknowledgements}

A special thank to FRIM-ITTO for the securing grant for this project and to members of FRIM for their supervision and commitment in this research work

\section{References}

Abdul Rashid, A.M., and Chew, L.T. (1990). Fire retardant treated chipboards, In. Pre-proceedings of a Conference on Forestry and Forest Product Resource. CFFPR-90, Malaysia,pp.37

Anonymous. (2009). Dipterocarpaceae-Shorea macrophylla-engkabang jantung, Species Information, Sarawak 
Forestry Department

Anonymous. (2009a). Second Schedule Part II on Protected Plants from the Wildlife Protection Ordinance, Sarawak Forestry Department

Flackenstein, R. (2009). Which is better for hair, Illipe butter of Shea Butter?,Organic Skincare, Available online: http://organicskincare001.blogspot.com/2009/03/which-is-better-for-hair-illipe-or-shea.html

Izran, K., Koh. M.P., Tan, Y.E and Faezah, M. (2010). Buffering Capacity of Fast-Growing Species and Curing Time of UF Resin Modified with Zinc Borate and Monoammonium Phosphate, Unpublished report of FRIM-ITTO Project 2009.

Izran, K., Zaidon, A., Abdul Rashid, A.M, F., Abood, Mohamad Jani, S., Zaihan, J. and Faezah, M. (2009a). A preliminary study in Determining the Curing Time of Urea Formaldehyde resin mixed with different concentrations of fire retardants and assessments of its properties, In. Proceedings of National Postgraduate Conference on Engineering, Science and Technology, Malaysia, pp.89

Izran, K., Zaidon, A., Abdul Rashid, A.M. and Abood, F. (2009b). Fire Performance and Properties of Particleboard Made From Kenaf Core Treated with Fire Retardants, MSc. thesis, Universiti Putra Malaysia.

Izran, K., Zaidon, A., Abdul Rashid, A.M., Abood, F., Mohd. Nor,M.Y., and Masseat, K. (2009). Physical and Mechanical Properties of Flame-Retardant Treated Hibiscus cannabinus Particleboard, Journal of Modern Applied Science 3(8):2-8

Mohamad Azani, A., Nik Muhammad Majid, and Meguro, S. (2001). Rehabilitation of Tropical Rainforests Based on Indigenous Species for Degraded Areas in Sarawak, Malaysia, In. Workshop Proceedings of Rehabilitation of Degraded Tropical Forest Ecosystems,2-4 November 1999, Bogor, Indonesia, Center for International Forestry Research, Bogor, Indonesia, pp.226

Muehl,H.J.,Kryzsik, M.A., Youngquist, A.J., Chow, P, \& Bao, Z. (1999). Performance of hardboard made from kenaf, In. Terry Sellers, J.R., Nancy A. Reichert, Eugene P. Columbus. Marty J. Fuller, and Karen Williams (Eds.), Kenaf properties:processing and products. Mississippi State University

Sanchez, R.L. (2006). Acacia mangium, Finca Leola Costa Rica Reforestation, available online : http://www.fincaleola.com/acacia.html

Velez Torres, D.A and Valle Del, J.I. (2007). Growth and Yield Modelling of Acacia mangium in Colombia, Journal of New Forests 34(3):293-305

White, H.R. and Sweet, M.S. (1992). Flame Retardancy of Wood: Present Status, Recent Problems, And Future Fields In. Recent Advances in Flame Retardancy of Polymeric Materials: Proceedings of $3^{\text {rd }}$ annual BCC Conference. on Flame Retardance, Stamford CT. Norwalk, CT: Business Communications Company, Inc,pp. 250-257

Winandy,J. And Wang, Q., and White, R.H. (2008). Fire Retardant-Treated Strandboard: Properties and Fire Performance, Journal of Wood Fibre and Science, 40(1):62-71

Xavier, V.P. (2009). Using Acacia mangium as a single material in producing particleboard, presented to Jayakuik Sdn Bhd by a staff of Universiti Malaysia Sabah, Available online: www.jayakuik.com.my/event/victorviva.pps

Zhiyong, C., Muehl, H.J and Winandy, J.E. (2006). Effect of pressing schedule on formation of vertical density profile for MDF boards, In Proceedings of $40^{\text {th }}$ International Wood Composites Symposium, 11-12 April 2006, Seattle, Washington D.C. 
Table 1. Parameters for producing a particleboard

\begin{tabular}{ll}
\hline Raw Material & $\begin{array}{l}\text { Engkabang and Acacia mangium }(1-2 \\
\mathrm{mm} \text { particle size) }\end{array}$ \\
\hline Targeted board density & $700 \mathrm{~kg} / \mathrm{m}^{3}$ \\
Targeted board MC & $12 \%$ \\
Board Size & $(350 \times 350 \times 12) \mathrm{mm}^{3}$ \\
Adhesive & \\
UF resin & $12 \%$ (w/w of dried particles) \\
Hardener $\left(\mathrm{NH}_{4} \mathrm{Cl}\right)$ & $3 \% \quad($ based on resin) \\
Wax & $1 \% \quad$ (based on dried particles) \\
Fire retardants & $10 \%$ (w/w of dried particles) \\
1.monoammonium phosphate $(\mathrm{MAP})$ & \\
2. zinc borate $\left(4 \mathrm{Zn} 0.6 \mathrm{~B}_{2} \mathrm{O}_{3} .7 \mathrm{H}_{2} \mathrm{O}\right)$ & \\
\hline
\end{tabular}

Table 2. Physical and mechanical performances of fire retardant-treated engkabang and Acacia mangium particleboards.

\begin{tabular}{cccccccc}
\hline & & & \multicolumn{5}{c}{ Fire retardant-treated samples } \\
\hline Performance & Standard & Control & MAP-Eng & ZBr-Eng & Cont-AM & MAP-AM & ZBr-AM \\
& requirements & - Eng \pm S.D & \pm S.D & \pm S.D & \pm S.D & \pm S.D & \pm S.D \\
\hline 1 1TS (\%) & NA & $5.46^{\mathrm{a}} \pm 0.8$ & $4.69^{\mathrm{a}} \pm 0.7$ & $8.09^{\mathrm{a}} \pm 1.6$ & $3.30^{\mathrm{a}} \pm 0.6$ & $4.64^{\mathrm{a}} \pm 0.2$ & $6.93^{\mathrm{a}} \pm 0.9$ \\
& & & $(-0.77)$ & $(2.63)$ & & $(1.34)$ & $(3.63)$ \\
$2 \mathrm{TS}(\%)$ & $\leq 16 \%$ & $20.57^{\mathrm{a}} \pm 5.9$ & $16.34^{\mathrm{b}} \pm 1.7$ & $36.47^{\mathrm{c}} \pm 3.8$ & $8.82^{\mathrm{a}} \pm 0.8$ & $20.10^{\mathrm{b}} \pm 9.4$ & $26.07^{\mathrm{c}} \pm 1.2$ \\
& & & $(-4.68)$ & $(4.68)$ & & $(11.28)$ & $(17.25)$ \\
1WA (\%) & $\mathrm{NA}$ & $13.42^{\mathrm{a}} \pm 2.1$ & $10.34^{\mathrm{b}} \pm 1.1$ & $16.12^{\mathrm{c}} \pm 3.0$ & $8.09^{\mathrm{a}} \pm 1.6$ & $9.19^{\mathrm{a}} \pm 4.0$ & $12.77^{\mathrm{a}} \pm 1.5$ \\
& & & $(-0.38)$ & $(2.7)$ & & $(1.1)$ & $(4.68)$ \\
$2 \mathrm{WA}(\%)$ & $\mathrm{NA}$ & $45.69^{\mathrm{a}} \pm 9.5$ & $35.99^{\mathrm{b}} \pm 1.8$ & $64.51^{\mathrm{c}} \pm 8.4$ & $20.38^{\mathrm{a}} \pm 1.2$ & $35.62^{\mathrm{a}} \pm 14.0$ & $48.37^{\mathrm{a}} \pm 5.2$ \\
& & & $(-9.7)$ & $(18.82)$ & & $(15.24)$ & $(27.99)$ \\
$\mathrm{MOR}$ & $\geq 14 \mathrm{~N} / \mathrm{mm}^{2}$ & $21.17^{\mathrm{a}} \pm 4.0$ & $17.42^{\mathrm{b}} \pm 5.0$ & $14.08^{\mathrm{c}} \pm 3.5$ & $20.64^{\mathrm{a}} \pm 3.6$ & $14.42^{\mathrm{b}} \pm 4.0$ & $13.23^{\mathrm{c}} \pm 2.1$ \\
$\left(\mathrm{~N} / \mathrm{mm}^{2}\right)$ & & & $(-17.71)$ & $(-33.49)$ & & $(-30.13)$ & $(-35.9)$ \\
$\mathrm{MOE}\left(\mathrm{N} / \mathrm{mm}^{2}\right)$ & $\geq 1800 \mathrm{~N} / \mathrm{mm}^{2}$ & $3924^{\mathrm{a}} \pm 447$ & $3337^{\mathrm{b}} \pm 337$ & $3155^{\mathrm{c}} \pm 532$ & $3483^{\mathrm{a}} \pm 702$ & $2818^{\mathrm{b}} \pm 499$ & $2940^{\mathrm{c}} \pm 404$ \\
& & & $(-14.96)$ & $(-19.59)$ & & $(-19.09)$ & $(-15.59)$ \\
IB $\left(\mathrm{N} / \mathrm{mm}^{2}\right)$ & $\geq 0.4 \mathrm{~N} / \mathrm{mm}^{2}$ & $0.6^{\mathrm{a}} \pm 0.06$ & $0.57^{\mathrm{a}} \pm 0.05$ & $0.43^{\mathrm{a}} \pm 0.09$ & $0.90^{\mathrm{a}} \pm 0.12$ & $0.68^{\mathrm{a}} \pm 0.23$ & $0.36^{\mathrm{a}} \pm 0.1$ \\
& & & $(-5.0)$ & $(-28.33)$ & & $(-24.44)$ & $(-60.0)$ \\
\hline
\end{tabular}

\footnotetext{
${ }^{1}$ Means within a row followed by the same alphabets under each species are not significantly different at $\mathrm{p} \leq 0.05$,

${ }^{2}$ Values in parentheses are percent change over untreated, ${ }^{3} 1 \mathrm{TS}=$ Thickness swelling and water absorption of samples immersed in cold water for $2 \mathrm{~h}, 2 \mathrm{TS}$ and $2 \mathrm{WA}=$ thickness swelling and water absorption of samples immersed in cold water for $24 \mathrm{~h}, \mathrm{MOR}=$ modulus of rupture, $\mathrm{MOE}=$ modulus of elasticity, $\mathrm{IB}=$ internal bond
} 


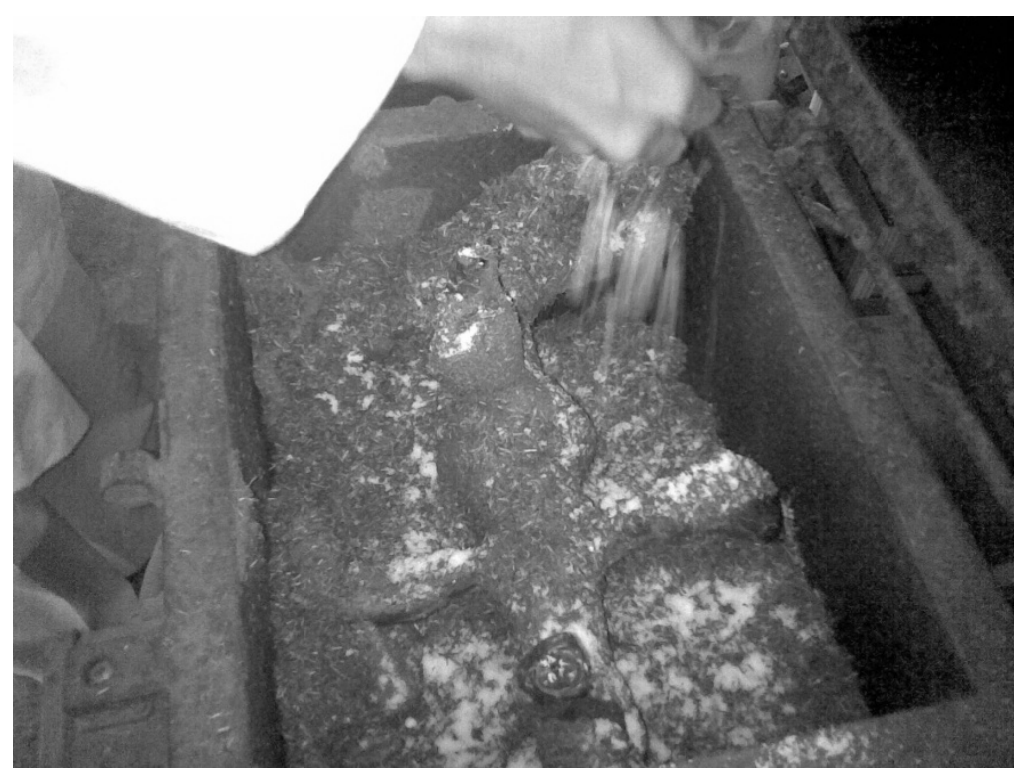

Figure 1. Scattering the fire retardant on the particle-adhesive mixture

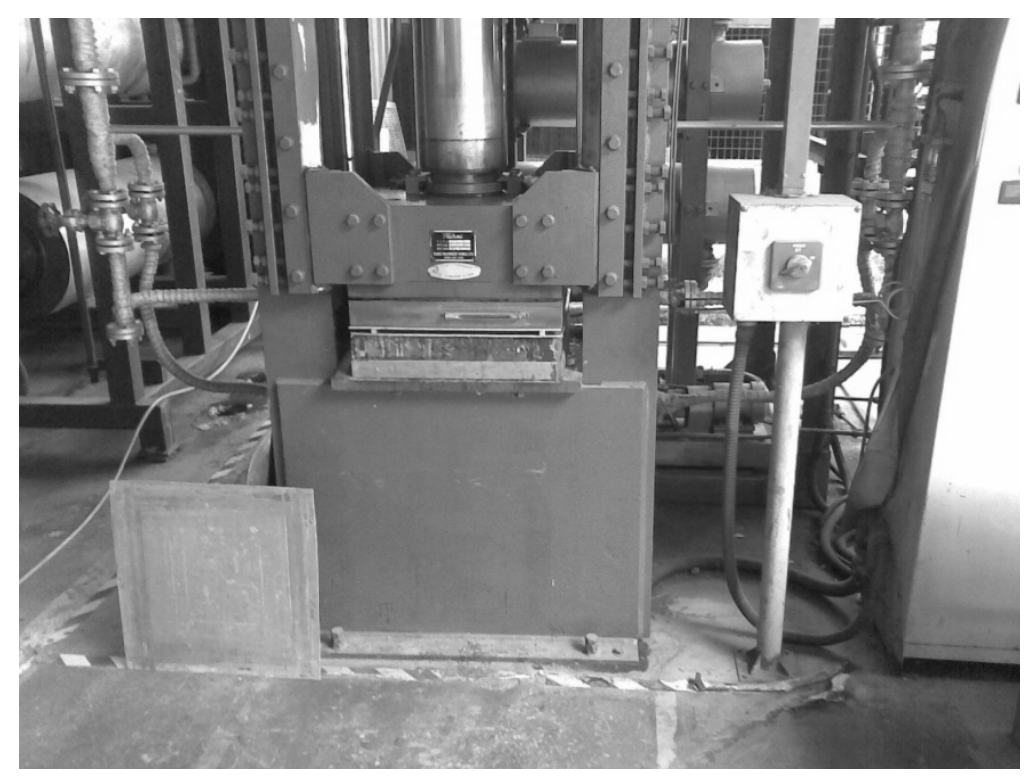

Figure 2. Hot pressing 